\title{
Histological Analysis of the Association between Formocresol and Endotoxin in the Subcutaneous Tissue of Mice
}

\author{
Ana Teresa SANT'ANNA ${ }^{1}$ \\ Luis Carlos SPOLIDÓRIO² \\ Lizeti Toledo Oliveira RAMALHO \\ ${ }^{1}$ Department of Pediatric Dentistry, School of Dentistry of Araraquara, \\ State University of São Paulo, Araraquara, SP, Brazil \\ ${ }^{2}$ Department of Pathology, School of Dentistry of Araraquara, State University of São Paulo, Araraquara, SP, Brazil \\ ${ }^{3}$ Department of Morphology, School of Dentistry of Araraquara, State University of São Paulo, Araraquara, SP, Brazil
}

\begin{abstract}
This study performed a histological analysis of the effect of formocresol associated to endotoxin (LPS) in the subcutaneous connective tissue of mice. Ninety mice were randomly assigned to 3 groups $(n=30)$. Each animal received one plastic tube implant containing endotoxin solution $(10 \mathrm{mg} / \mathrm{mL}$ ), formocresol (original formula) or a mixture of endotoxin and formocresol. The endotoxin and formocresol groups served as controls. The periods of analysis were 7, 15 and 30 days. At each experimental period, tissue samples were collected and submitted to routine processing for histological analysis. Endotoxin and formocresol produced necrosis and chronic inflammation at 7 and 15 days. At 30 days, the endotoxin group showed no necrosis, while in the formocresol group necrosis persisted. The formocresol-endotoxin association produced necrosis and chronic inflammation in the same way as observed with formocresol at all experimental periods. In conclusion, formocresol seems not to be able to inactive the toxic effects of endotoxin in connective tissues.
\end{abstract}

Key Words: formocresol, endotoxin, histological analysis, mice.

\section{INTRODUCTION}

Gram-negative bacteria can often be found in infected root canals with necrotic pulps and may play an important role in the development of periapical lesions, bone resorption and signs and symptoms of endodontic pathosis (1-4). These bacteria have cytoplasmatic membranes and cell walls formed by proteins, lipoproteins and lipopolysaccharides called LPS or endotoxin. Endotoxin is released when the cell walls of gram-negative bacteria undergo lysis or during duplication (5). They are capable of triggering several biological responses, such as complement system activation, which enhances vascular permeability, causes vasodilatation and attracts polymorphonuclear leukocytes and macrophages chemotactically (6-8). Primary teeth with pulp necrosis also present these bacteria.
A retrospective human study has proposed formocresol for endodontic treatment in pediatric dentistry even for vital and non-vital pulp and this material has reached successful results in clinical and radiographic investigations $(9,10)$, being recommended for primary endodontic treatment by the International Clinical Guidelines in Pediatric Dentistry $(11,12)$.

Formocresol has antimicrobial and fixative properties that preserve periapical integrity. However, components of formocresol formulation, especially formaldehyde, have controversial properties, being implicated in the occurrence of periapical changes, alteration of the healing process, systemic distribution in animal organs and mutagenic effects (13-17).

Considering that formocresol has been successfully used for the endodontic treatment of primary teeth with root canal infection by gram-negative bacteria, this 
study performed a histological analysis of the effect of formocresol associated to endotoxin (LPS) in the subcutaneous connective tissue of mice.

\section{MATERIAL AND METHODS}

The research proposal was independently reviewed by the institutional Ethics in Animal Research Committee and the study design was approved. The ethical guidelines from the NIH Guide for the Care and Use of Laboratory Animals were followed. The number of animals and the duration of the experiment were in agreement with the recommended standard practices for biological evaluation of dental materials (18).

Ninety male mice (Mus muscullus albinus) weighing 30 to $40 \mathrm{~g}$ were selected and housed in individual cages at room temperature with free access to water and food throughout the course of the study. The animals were randomly assigned to 3 groups $(n=30)$, each of them receiving plastic tube implants containing one of the tested materials: endotoxin solution $(10 \mathrm{mg} /$ $\mathrm{mL}$ ), formocresol (original formula) or endotoxin/ formocresol mixture.

A bacterial endotoxin (LPS) obtained from lyophilized Escherichia coli (Serotype 055:B5) extract (Sigma-Aldrich Sigma Chemical Co., St. Louis, MO, USA) was used. The endotoxin was dissolved in sterile buffered phosphate saline solution to a concentration of $10 \mathrm{mg} / \mathrm{mL}$ (1). This solution was divided in 5 portions of $1 \mathrm{~mL}$ of endotoxin that were stored in Eppendorf tubes. The endotoxin-formocresol mixture was obtained by adding $1 \mathrm{~mL}$ of formocresol (Sultan Chemists, Inc., Englewood, NJ, USA) to one of the Eppendorf tubes containing $1 \mathrm{~mL}$ of endotoxin. The materials under study were placed into sterile plastic tubes to be implanted in the subcutaneous connective tissue of the mice. The plastic tubes $(2 \mathrm{~mm}$ inner diameter; $1 \mathrm{~cm}$ high) had one of their sides closed with a heated instrument and were autoclaved before use.

For implantation of the tubes containing the materials, the mice were anesthetized with an intraperitoneal injection of sodium thiopental (Thionembutal; Abbot Laboratories, Chicago, IL, USA; $40 \mathrm{mg} / \mathrm{kg}$ ) at a dose of $0.2 \mathrm{~mL} / 100 \mathrm{~g}$ body weight. Antisepsis of the site of implantation was done with iodated alcohol. A 1-cm long incision was made along the lumbar region of the dorsal skin, which was separated with scissors and the plastic tube with the material was implanted in the subcutaneous connective tissue. The plastic tube was placed parallel to the long axis of the animal's body, with the open edge turned to the cervical region (Fig. 1).

The animals were sacrificed by anesthetic overdose 7, 15 and 30 days after implant placement. The skin with the tube was excised, spread apart with filter paper and fixed for $24 \mathrm{~h}$ in phosphate-buffered formalin. After fixation, the tissue was embedded in paraffin and submitted to routine processing for histological analysis. The plastic tube was removed and the tube space was filled with paraffin. The paraffin-embedded tissue blocks were serially sectioned into $6-\mu \mathrm{m}$-thick sections that were stained with hematoxylin and eosin, and Masson's Trichrome.

Histological analysis was performed under light microscopy, using the following criteria to determine tissue reaction. Mild Tissue Reaction: 2 weeks after implantation, the connective tissue was well organized with no inflammatory reaction in the region in contact with the material at the tube ends and along its midsection; Moderate Tissue Reaction: 2 weeks after implantation, some inflammatory cells were present at the tube ends and none was found along its midsection. The connective tissue adjacent to the test material structurally preserved, but presented leukocytes (no remarkable accumulation), lymphocytes, plasma cells, macrophages and occasional foreign body cells; Severe Tissue Reaction: 2 weeks after implantation, differentiated

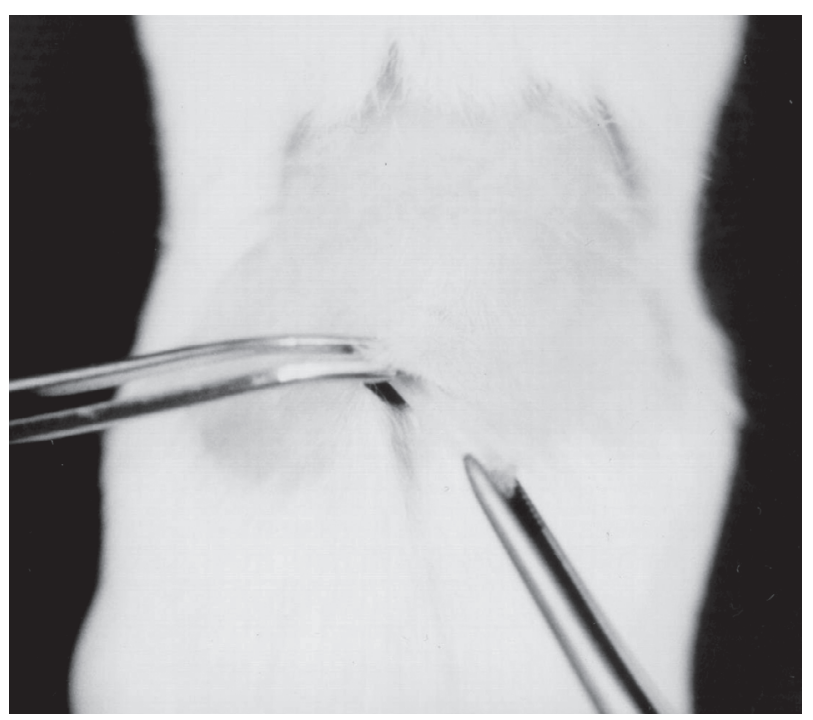

Figure 1. Plastic tube with the test material being implanted into the subcutaneous connective tissue of a mouse. 
tissue reaction was found at the tube ends and fibrous inflamed tissue along its midsection. Tissue at the tube ends had lost its structure and showed an accumulation of neutrophil leukocytes and lymphocytes (18).

\section{RESULTS}

\section{Endotoxin}

At the 7th and 15th day, the connective tissue showed severe tissue reaction. A liquid necrosis associated with acute inflammatory areas was seen, with neutrophil infiltrate, mononuclear cells and vascular dilatation with hemorrhage (Figs. 2A,B). At the 30th day, there was no necrosis, and tissues showed chronic inflammation with polymorphonuclear and mononuclear cells surrounded by granulation tissue. This granulation tissue had proliferation of fibrous and vascular structures that were associated with the healing process, and severe tissue reaction was observed (Fig. 2C).

\section{Formocresol}

Formocresol promoted a coagulation necrosis associated to the inflammation process with mononuclear cells and dilatation of the vessels with fibril new formation at the 7 th day (Fig. 3A). At the 15th day, the cell picture was similar but, at this time, the tissue showed negative areas uncovered by fibrotic tissue, probably caused by material vapors (Fig. 3B). At the 30th day, the negative areas decreased, but necrosis and inflammation persisted. This group showed severe tissue reaction in all experimental periods (Fig. 3C).

\section{Endotoxin/Formocresol}

This group showed a combination of events. At the 7th day, the tissue showed liquid necrosis with negative areas surrounded by reactive tissue (Fig. 4A). At 15 days, the tissue showed no negative areas, but the necrosis was persistent and surrounded by fibrous tissue (Fig. 4B). At the 30th day, necrosis decreased, but was still persistent. The necrotic areas were covered by small inflammatory tissue areas and associated to a large fibrous tissue, indicating an ongoing healing process (Fig. 4C). This group also showed severe tissue reaction in all experimental periods.

\section{DISCUSSION}

Endotoxin is a cell wall component of gramnegative bacteria. It is released when these bacteria
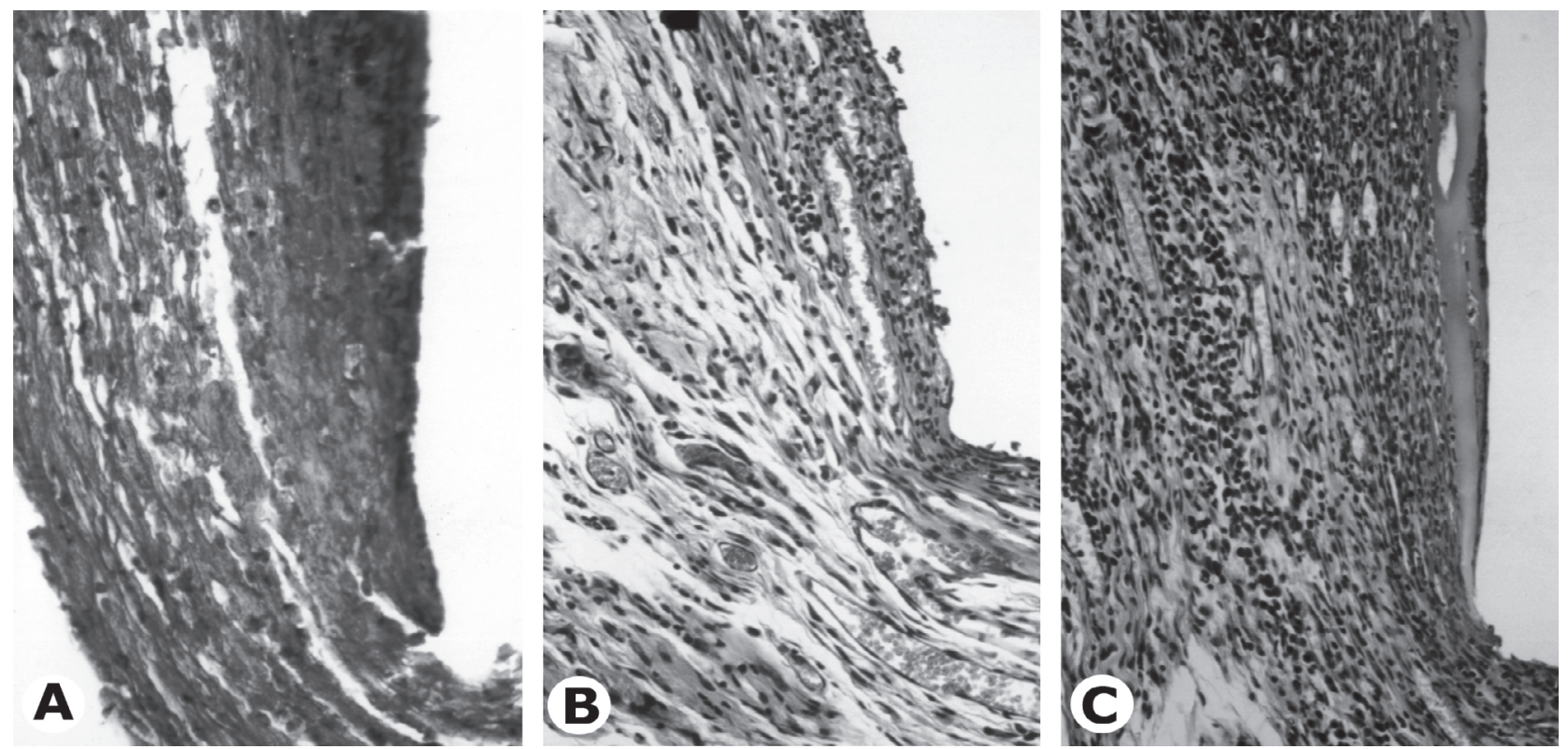

Figure 2. Endotoxin. A (7 days): Liquid necrosis associated to an acute inflammatory process $(\times 400)$. B (15 days): Necrosis with an associated acute inflammatory process $(\times 400)$. C (30 days): Chronic inflammation with no areas of necrosis $(\times 400)$. 


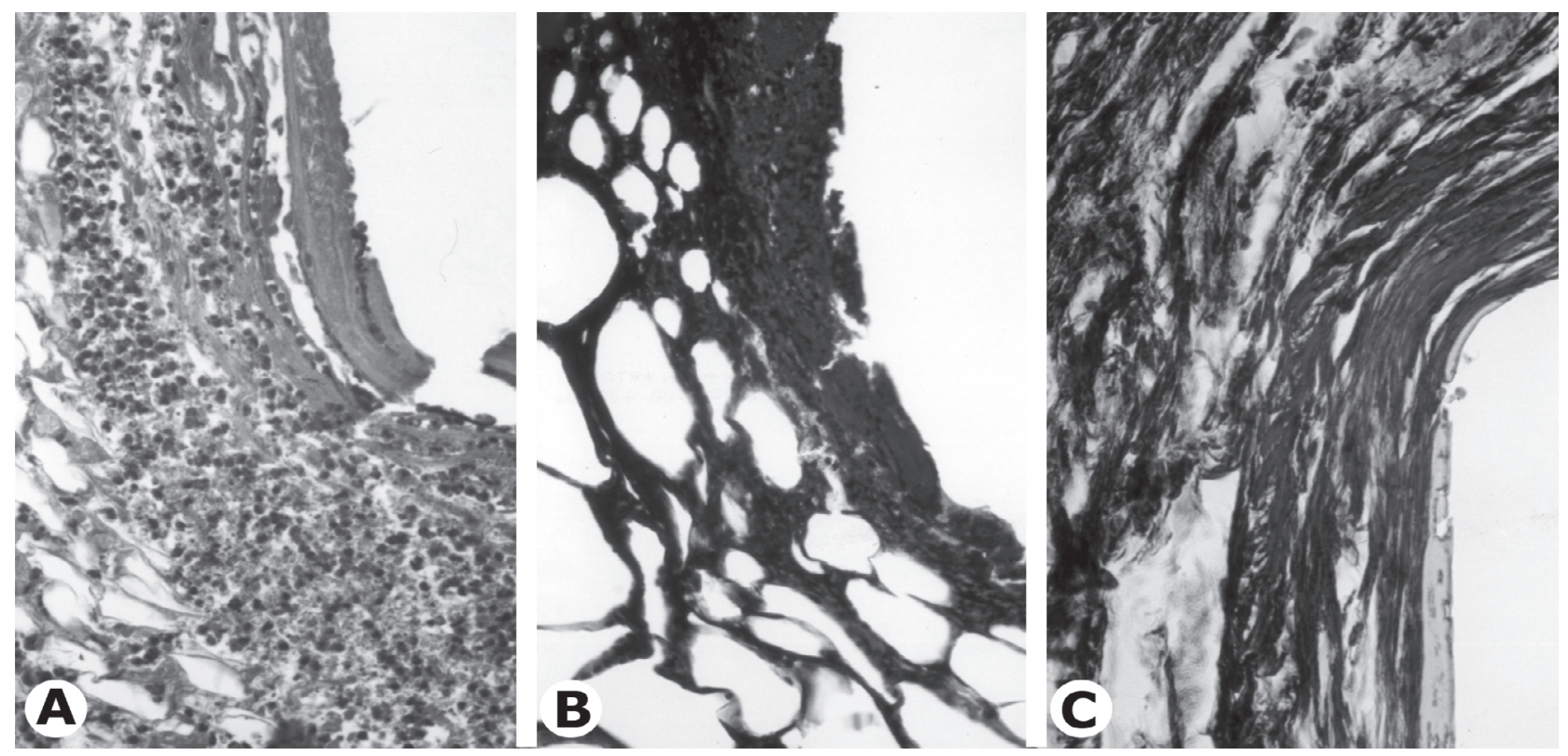

Figure 3. Formocresol. A (7 days): Coagulation necrosis associated to an acute inflammatory process $(\times 600)$. B (15 days): Coagulation necrosis with inflammation and negative areas $(\times 400)$. C (30 days): Coagulation necrosis with inflammation and small negative areas $(\times 600)$.
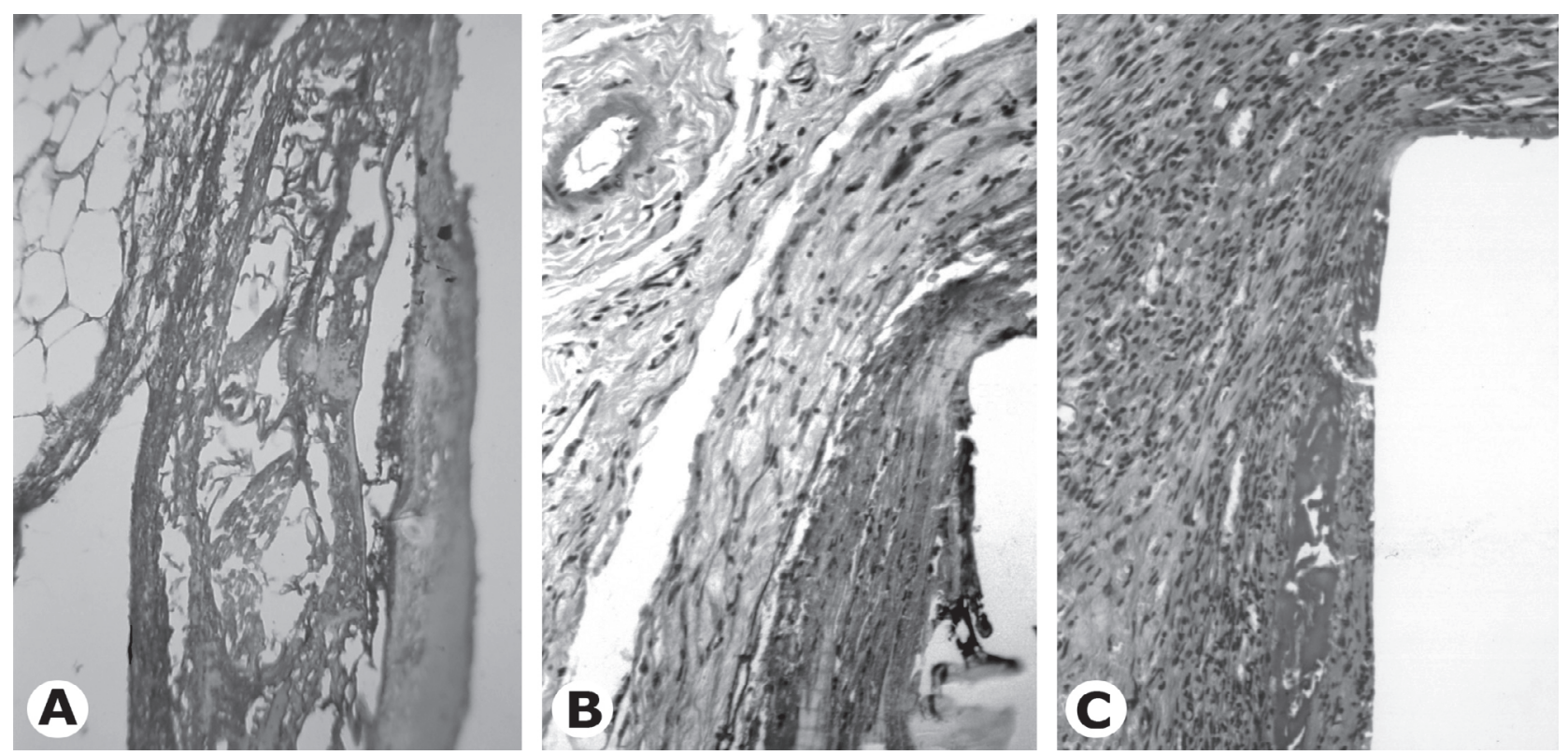

Figure 4. Endotoxin/Formocresol. A (7 days): Liquid necrosis with negative areas surrounded by reactive tissue ( $\times 400)$. B (15 days): Necrosis surrounded by fibrous tissue $(\times 400)$. C (30 days): Small necrosis and inflammation areas associated to a large fibrous tissue area $(\times 400)$.

duplicate or die. Endotoxin is composed of three regions: core, O-chain and lipid $\mathrm{A}$, the toxic portion of the molecule. Several studies have demonstrated that endotoxin can activate inflammatory cells like macroph- ages and neutrophils, thus releasing some chemical mediators, interleukins (IL-1, IL-1, IL-6, IL-8) and tumor necrosis factor (TNF). It can also activate the classic and alternate pathway of the complement and 
aracdonic acid cycle $(2,6-8,19)$. The toxic effects of the endotoxin are dose-dependent, and endotoxin reactions have been shown at different concentrations. In this study, $10 \mathrm{mg} / \mathrm{mL}$ were used, which is the same concentration used by Dahlén (1).

The necrosis and acute inflammation promoted by the endotoxin in the 7- and 15-day periods can be explained by the irritating action of this material on biological tissues, activating cell responses by the release of chemical mediators. On the 30th day, the tissue showed chronic inflammation and no necrosis, thus indicating an ongoing healing process. Munford and Hall (20) demonstrated that the toxicity caused by lipopolysaccharides is reduced by enzymatic activity in human neutrophils (acyloxyacyl hydrolysis). This enzyme removes fatty acid chains that are linked to the hydroxyl groups and reduces the bioactive lipid A moiety of the lipopolysaccharides.

Formocresol is a popular endodontic material in pediatric dentistry. The use of this substance has been taught at dental schools worldwide because of its clinical and radiographic success (10). Nevertheless, several investigations (13-17) have also demonstrated that formocresol produces toxic effect in connective tissue, probably because of the presence of formaldehyde in its formulation.

The findings of the present study showed that formocresol promoted necrosis and inflammatory reactions in the connective tissue at the earlier period, and that, at 15 days, the same features were observed in addition to negative areas surrounded by fibrotic tissue. At the 30th day, the tissue still showed necrosis, inflammation and negative areas, but was all these events were milder. These findings agree with those of Loos et al. (15) and Yamasali et al. (16), who demonstrated that formocresol promoted damage and delayed the healing process.

In conclusion, combination of formocresol and endotoxin produced the same toxic effects seen with formocresol and endotoxin alone, with necrosis, acute inflammation and negative areas at the 7- and 15-day periods. At 30 days, the necrotic areas were smaller and the connective tissue showed fibrosis. The presence of necrosis in the latest period of the formocresol/endotoxin group and its absence in the endotoxin group showed that the formocresol delayed the healing process and that formocresol seems not to be able to inactive the toxic effects promoted by endotoxin.

\section{RESUMO}

O objetivo deste estudo foi avaliar histologicamente o efeito da associação do formocresol com endotoxina (LPS) em tecido conjuntivo de camundongos. Noventa camundongos foram divididos em três grupos de 30 camundongos cada. Cada camundongo recebeu um implante subcutâneo de tubo plástico contendo solução de endotoxina $(10 \mathrm{mg} / \mathrm{ml}$ ), formocresol (fórmula original), ou uma mistura de formocresol com endotoxina. Os grupos da endotoxina e formocresol foram considerados grupos controle. Os períodos de análise foram 7, 15 e 30 dias. Após os períodos experimentais, os tecidos foram removidos e submetidos a processamento histológico. Os resultados obtidos indicam que a endotoxina e o formocresol produzem necrose e inflamação tecidual crônica aos 7 e 15 dias e aos 30 dias o grupo da endotoxina não mostrava necrose e no grupo do formocresol a necrose persistiu. A combinação formocresol e endotoxina mostrou necrose e inflamação crônica com resultados semelhantes ao do grupo formocresol para todos os períodos experimentais. Podese concluir que o formocresol parece não ser capaz de inativar os efeitos tóxicos da endotoxina.

\section{REFERENCES}

1. Dahlén G, Magnusson BC, Moller A. Histological and histochemical study of the influence of lipopolysaccharide extracted from Fusobacterium nucleatum on the periapical tissues in the monkey Macaca fascicularis. Arch Oral Biol 1981;26:591-598.

2. Jacinto RC, Gomes BP; Shah HN, Ferraz CC, Zaia AA, SouzaFilho FJ. Quantification of endotoxins in necrotic root canals from symptomatic and asymptomatic teeth. J Med Microbiol 2005;54:777-783.

3. Mattison GD, Haddix JE, Kehoe JC, Progulske-Fox A. The effect of Eikenella corrodens endotoxin on periapical bone. J Endod 1987; 13:559-565.

4. Pitts DL, Williams BL, Morton Jr TH. Investigation of the role of endotoxin in periapical inflammation. J Endod 1982;8:10-18.

5. Rietchield I, Brade H. Bacterial endotoxins. Sci Am 1992;2633.

6. Barkhordar RA, Hayashi C, Hussain MZ. Detection of interleukin-6 in human dental pulp and periapical lesions. Endod Dent Traumatol 1999;15:26-27.

7. Barthel CR, Levin LG, Reisner HM, Trope M. TNF-a release in monocytes after exposure to calcium hydroxide treated Escherichia coli LPS. Int Endod J 1997;30:155-159.

8. Matsushita K, Tajima T, Tomita K, Takada H, Nagaoka S, Torii M. Inflammatory cytokine production and specific antibody responses to lipopolysaccharide from endodontopathic black-pigmented bacteria in patients with multilesional periapical periodontitis. J Endod 1999;25:795799.

9. Hill MW. The survival of vital and non-vital deciduous molar teeth following pulpotomy. Aust Dent J 2007;52:181-186.

10. Boeve C, Dermaut L. Formocresol pulpotomy in primary molars: a long-term radiographic evaluation. ASDC J Dent Child 1982;49:191-196.

11. Haney KL. Current trends in primary tooth pulp therapy. J Okla Dent Assoc 2007;99:28-37. 
12. Llewelyn DR. UK National clinical guidelines in paediatric dentistry. Int J Pediatric Dent 2000;10:248-252.

13. Block RM, Lewis RD, Hirsch J, Coffey J, Langerland K. Systemic distribution of $14 \mathrm{C}$ labeled paraformaldehyde incorporated within formocresol following pulpotomies in dogs. $\mathrm{J}$ Endod 1983;9:176-189.

14. Myers DR, Pashley DH, Whitford GM, McKinney RV. Tissue changes induced by the absorption of formocresol from pulpotomy sites in dogs. Pediatr Dent 1983;5:6-8.

15. Loos PJ, Straffon LH, Han SS. Biological effects of formocresol. ASDC J Dent Child 1973;40:193-197.

16. Yamasaki M, Nakamura H, Kameyama Y. Irritating effect of formocresol after pulpectomy in vivo. Int Endod $\mathrm{J}$ 1994;27:245-251.

17. Ramos ME, Cavalcanti BC, Lotufo LV, de Moraes MO, Cerqueira Ede M, Pessoa C. Evaluation of mutagenic effects of formocresol: detection of DNA-protein cross-links and micronucleus in mouse bone marrow. Oral Surg Oral Med Oral Pathol Oral Radiol Endod 2008;105:398-404.

18. Recommended standard practices for biological evaluation of dental materials. Federation Dentaire International, Commission of Dental Materials, Instruments, Equipment and Therapeutics. Int Dent J 1980;30:140-188.

19. Morrison B, Kline L. Activation of classical and propertin pathways of complement by bacterial lipopolysaccharides (LPS). J Immunol 1977;118:362-368.

20. Munford RS, Hall CL. Detoxification of bacterial lipopolysaccharides (endotoxins) by a human neutrophil enzyme. Science 1986;234:203-205.

Accepted October 30, 2006 